\title{
Characterisation of gold tailings dams of the Witwatersrand Basin with reference to their acid mine drainage potential, Johannesburg, South Africa
}

\author{
AC Nengovhela ${ }^{1 *}$, B Yibas ${ }^{2}$ and JS Ogola1 \\ ${ }^{1}$ Department of Mining and Environmental Geology, University of Venda for Science and Technology, Private Bag X 5050, \\ Thohoyandou 0950, South Africa \\ ${ }^{2}$ Council for Geoscience, Private Bag X112, Pretoria 0001, South Africa
}

\begin{abstract}
Factors which play a role in acid mine drainage (AMD) formation were investigated over a period of 12 months. These include climatic, mineralogical, hydrological and oxygen diffusion parameters. The oxygen diffusion data reveal that the flow of oxygen in the Witwatersrand tailings dams is controlled by secondary porosity (i.e. cracks caused by roots on the dam surface). The age of the dam does not have a significant bearing on the extent to which the oxidised zone development and subsequently AMD can progress. Most of these processes take place within the first $3 \mathrm{~m}$ of the dams. The amount of rainfall plays a crucial role in determining the extent to which an oxidised zone progresses. The average oxidised zone in the 5 sites is $2.4 \mathrm{~m}$ ranging from 2.2 to $3.5 \mathrm{~m}$.
\end{abstract}

Keywords: oxidised zone, oxygen diffusion, $\mathrm{pH}$, acid mine drainage

\section{Introduction}

In tailings storage facilities, AMD occurs when sulphide minerals in tailings are oxidised, because of exposure to moisture and oxygen. This results in the generation of sulphates, metals and acidity that can have manifold environmental consequences.

When AMD is generated, it can have undesirable effects on the ecosystem. Results can include contaminated water, disrupted growth and reproduction of aquatic plants and animals. Dissolved metals and acidity can also affect plant and animal populations.

Seven sites across the Witwatersrand Basin were identified for this study. However, two of the sites, i.e. $\mathrm{F}$ and $\mathrm{G}$ were only used to acquire the oxygen diffusion data. This means that only 5 sites were studied comprehensively. This is why in many instances in the paper only five sites are referred to. The sites are: Site A (Brakpan), Site B (Knights), Site C (Edenvale), Site D (Roodepoort), and Site E (Klerksdorp). Sites F and $\mathrm{G}$ are in Carletonville (Fig. 1 and Table 1).

The Witwatersrand Basin has a temperate climate, with the summer temperature averaging about $24^{\circ} \mathrm{C}$ and winter temperatures being about $13^{\circ} \mathrm{C}$, only occasionally dipping below the freezing point. Annual rainfall in Johannesburg is about $750 \mathrm{~mm}$ (Tyson and Wilcocks, 1971).

The prerequisite for AMD is the generation of acid at a faster rate than it can be neutralised by any alkaline materials in the waste. The most common culprit in AMD formation is pyrite. The oxidation of pyrite occurs in the following four steps:

* To whom all correspondence should be addressed.

푤 +27187818820 or +27769268106 ; fax: +27865122531 ;

e-mail colbert.nengovhela@goldfields.co.za

Received 16 May 2006; accepted in revised form 22 August 2006.

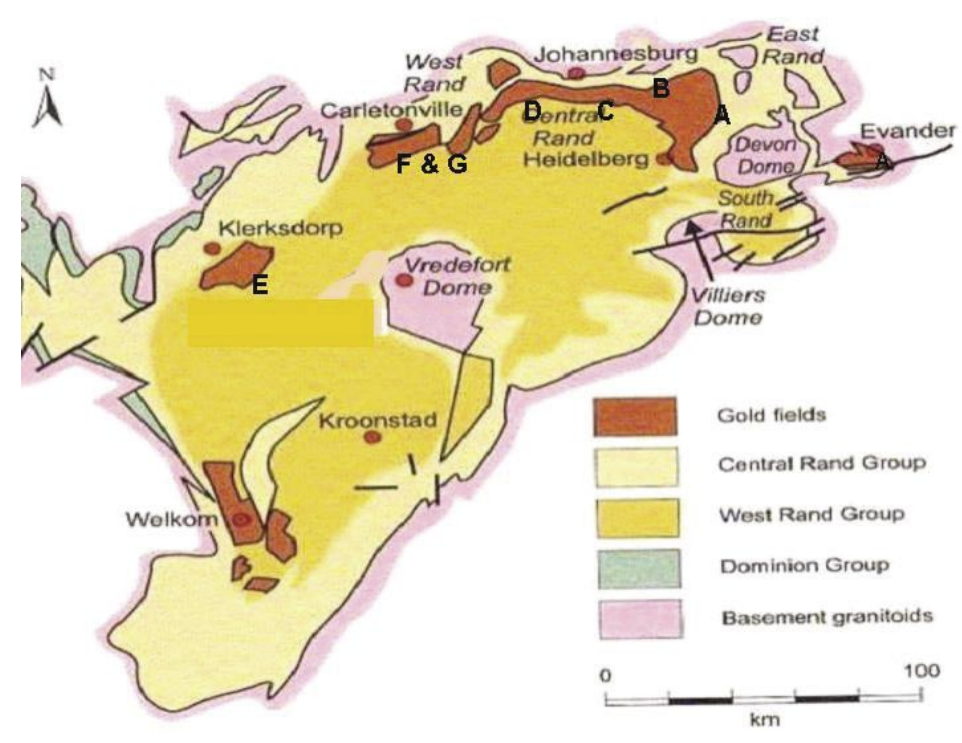

Figure 1

Geological map of the Witwatersrand Basin showing the locations of the 7 sites (Gold Fields, Driefontein Gold Mine, 2004)

$$
\begin{aligned}
& 2 \mathrm{FeS}_{2}+7 \mathrm{O}_{2}+2 \mathrm{H}_{2} \mathrm{O}=2 \mathrm{Fe}^{2+}+4 \mathrm{SO}_{4}^{2-}+4 \mathrm{H}^{+} \\
& 4 \mathrm{Fe}^{2+}+10 \mathrm{H}_{2} \mathrm{O}+\mathrm{O}_{2}=4 \mathrm{Fe}(\mathrm{OH})_{3}+8 \mathrm{H}^{+} \\
& 2 \mathrm{Fe}^{2+}+\mathrm{O}_{2}+2 \mathrm{H}^{+}=2 \mathrm{Fe}^{3+}+\mathrm{H}_{2} \mathrm{O} \\
& \mathrm{FeS}_{2}+14 \mathrm{Fe}^{3+}+8 \mathrm{H}_{2} \mathrm{O}=15 \mathrm{Fe}^{2+}+2 \mathrm{SO}_{4}^{2-}+16 \mathrm{H}^{+}
\end{aligned}
$$

The intensity of acid generation by these primary factors is determined by chemical parameters such as $\mathrm{pH}$, temperature and oxygen concentration in the gas and water phase and the surface area of the exposed metal sulphides (Ferguson and Erickson, 1988). Oxygen concentration inside a tailings dam varies depending on the degree of water saturation, temperature, the rate of water infiltration and the rate of 


\begin{tabular}{|l|c|c|c|c|c|}
\hline \multicolumn{7}{|l|}{ TABLE 1 } \\
Summary of available background information for the selected dams \\
\hline Site & Area (ha) & Height $(\mathbf{m})$ & Tonnage & $\begin{array}{c}\text { Material } \\
\left.\text { volume } \mathbf{( m}^{\mathbf{}}\right)\end{array}$ & $\begin{array}{c}\text { Decommis- } \\
\text { sioning date }\end{array}$ \\
\hline Site A & $\#$ & $10.5-22.5$ & 11 mill tons & $\#$ & 1950 s? \\
\hline Site B & 10 & 19 & $\#$ & 1028000 & 1973 \\
\hline Site C & 38 & 25 & $\#$ & 7828000 & 1976 \\
\hline Site D & 44.2 & 32 & $\#$ & 7576000 & 1975 \\
\hline Site E & $\#$ & 34 & $\#$ & $\#$ & 1973 \\
\hline Site F & $\#$ & $\#$ & $\#$ & 31422569 & 1997 \\
\hline Site G & $\#$ & $\#$ & $\#$ & $\#$ & 1999 \\
\hline
\end{tabular}

\# The information was not provided by the various mines concerned.

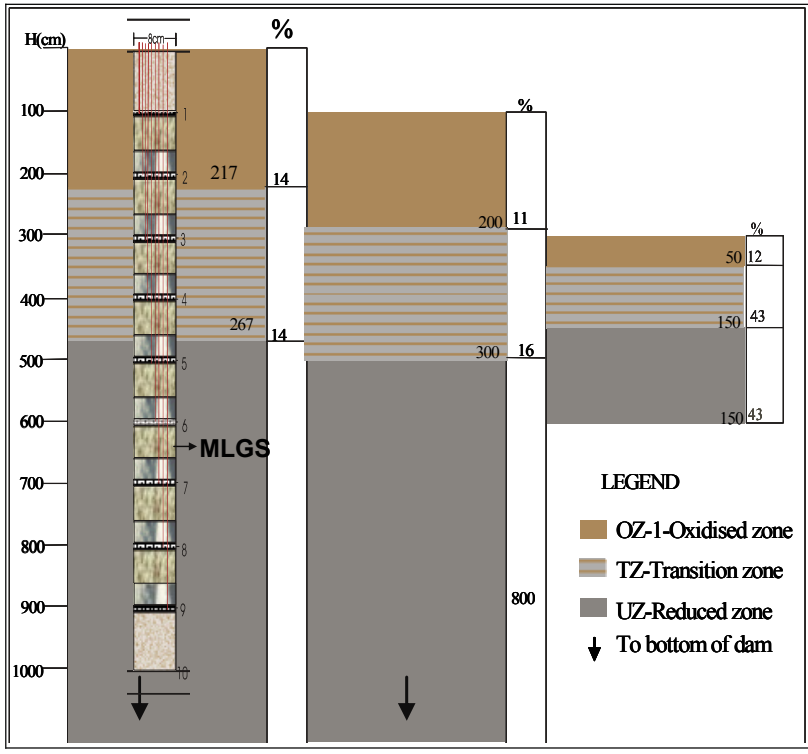

Figure 2

A division of the tailings dam profile into different zones at Site $B$. The same principle was applied to the other dams. Although the boundaries appear sharp in the figure, they are in actual fact, of a gradational nature. An exaggerated MLGS is inserted in the cross-section to indicate how the oxygen readings were taken.

oxygen consumption. Elberling et al. (1993) conducted field studies on uncovered unsaturated tailings deposits in Canada. They reported that the pore-gas oxygen concentration decreased from atmospheric concentrations ( $20.9 \mathrm{vol}-\%)$ to less than 5 vol$\%$ within the upper $600 \mathrm{~mm}$ of the impoundments. This shows that oxygen gradients exist in unsaturated tailings.

\section{Materials and methods}

Augering, and profile mapping were the two main methods used to collect samples from the different sites. Profile logging involves an adoption of the underground geological mapping method to map the profiles/cross-sections of tailings dams. This allows for the characterisation of the oxidation zones of the tailings dams based mainly on their ochreous (a moderate yelloworange to orange colour) appearance. The sampling was carried out between July 2004 and June 2005. Augers were manually drilled into the ground for a depth of up to $10 \mathrm{~m}$. An average of 100 samples was collected from each of the five sites. For laboratory analysis purposes, a composite sample was made to represent any particular zone in a particular tailings dam.

The instrument used for the measurement of oxygen is known as the Gas Alert Max, from BW Technologies. This instrument

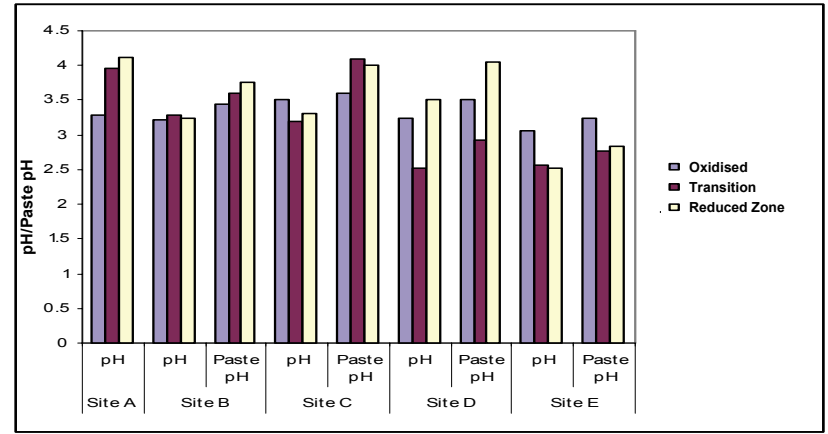

Figure 3

$p H$ and paste $p H$ for sites $A-E$. The graph illustrates that the first $10 \mathrm{~m}$ of the sampled Witwatersrand tailings dams is acidic.

pumps $\mathrm{O}_{2}$ at a rate of $250 \mathrm{~m} \ell / \mathrm{min}$ (minimum). Its detection range for oxygen is 0 to $30 \%$ in 0.1 increments and it uses a plug-in electrochemical cell sensor type. The $\mathrm{O}_{2}$ measuring principle used is the capillary-controlled concentration sensor that comes with an automatic calibration system. At each dam, a multilevel gas sampling system (MLGS) adopted from Shaw (2004) was constructed using $9 \times 6 \mathrm{~mm}$ diameter polyethylene sample tubes per dam (Fig. 2). This device has a built-in pipe which allows for the gas to be pumped from the various depths. The inlets of the sample tubes were placed between $200 \mathrm{~mm}$ thickness of $13 \mathrm{~mm}$ diameter gravel stones, i.e. $100 \mathrm{~mm}$ below and $100 \mathrm{~mm}$ above the port to prevent particulate uptake and to prevent clogging of the sample tubes. The MLGS was installed in the hole made by a hand auger of $80 \mathrm{~mm}$ diameter. The well screen at the bottom of the centre stock extended to a depth of $10 \mathrm{~m}$ with a $0.9 \mathrm{~m}$ bentonite layer between the $9^{\text {th }}$ and $10^{\text {th }}$ meter level to minimise vertical air flow from the bottom of the tailings dams.

Fine-grained sand $(0.2$ to $0.3 \mathrm{~mm})$ was placed in between each sampling port for a width of $600 \mathrm{~mm}$ to minimise the vertical movement of pore gas. Coarse-grained sand $(0.8$ to $1.0 \mathrm{~mm})$ was placed immediately above the $20 \mathrm{~mm}$ of gravel for a width of $30 \mathrm{~mm}$ to promote horizontal flow of the pore-gas. At the tailings surface the annular space in the drill hole was sealed to 0.9 $m$ depth with bentonite. Due to the age of the dams, and the fact that they were being reclaimed at the time of the experiment no water table was encountered at any of the sites.

Extensive laboratory work at the Council for Geosciences, Soil Lab and PHD Inc. laboratories was carried out to determine different properties and characteristics of tailings material. The collected samples were subjected to various analytical procedures listed below.

For geochemical characterisation; XRD analyses were done at the Council for Geoscience Laboratory using a Siemens D500 X-ray goniometer equipped with $\mathrm{Cu}$ tube, variable slit and 
secondary graphite monochromator. For water extraction analyses, tailings materials were weighed accurately on an analytical balance to not more than $100.00 \mathrm{~g}$ into clean (unused) $1.5 \ell$ plastic bottles. One litre distilled deionised water was added to each sample bottle, whereafter all samples were placed on a horizontal shaker and agitated at $130 \mathrm{r} / \mathrm{min}$ for $24 \mathrm{~min}$. After agitation, the samples were removed and left to stabilise for approximately $8 \mathrm{~h}$. The samples were then filtered through Whatman No 1 filter papers into marked sample bottles. Sulphuric acid was added to each sample for preservation. Paste $\mathrm{pH}$ done at the PHD Inc. laboratory involved making a 1:10 ratio of sample to water, measured after $24 \mathrm{~h}$, which allowed for a more realistic determination of the current $\mathrm{pH}$ and also allowed reactions to be more complete than an instantaneous or $10 \mathrm{~min}$ analysis. To prevent ingress of oxygen, which may accelerate oxidation of the tailings, into the sample, the material was sealed immediately after the addition of water. The $\mathrm{pH}$ was determined by adding water to the sample and subjecting it to vigorous shaking for a short time (i.e. $1 \mathrm{~h}$ ). This allowed for soluble particles in the samples to be dissolved thereby giving a more accurate measure of the $\mathrm{pH}$ of a sample.

Determination of hydraulic properties (estimation of porosity and analysis of permeability of the tailings material); particle size distribution (PSD) (sieve + hydrometer); water retention characteristics calculations; and moisture content determination were all carried out by Soil Lab.

\section{Results and discussion}

In the field, the five sites were all divided into three zones, namely; oxidised, transition and reduced zones. Figure 2 is a schematic representation of such zones at one of the sites. The established oxidation zone thicknesses from profile logging are; Site $\mathrm{A}=3.4 \mathrm{~m}, \mathrm{~B}=2.2 \mathrm{~m}$, $\mathrm{C}=2.1 \mathrm{~m}, \mathrm{D}=3.5 \mathrm{~m}$, and $\mathrm{E}=1 \mathrm{~m}$.

The $\mathrm{pH}$ and paste $\mathrm{pH}$ of tailings dams (Fig. 3) give an indication of the acidic drainage that a tailings dam is already generating. Site A shows an increasing $\mathrm{pH}$ with depth and the rest of the sites are not definitive. The $\mathrm{pH}$ at the reduced zone of Site A is however, still acidic at 4.11. Coincidentally this is the highest $\mathrm{pH}$ of all the sites. At Site $\mathrm{B}$, the $\mathrm{pH}$ increases in the transition zone. Site $\mathrm{E}$ shows the lowest $\mathrm{pH}$ in the transition and reduced zones with the reduced zone having the lowest $\mathrm{pH}$ of 2.52 of all the study sites. This is only equalled by the transition zone's $\mathrm{pH}$ of Site D. This site (i.e. E) is the only one that has a decreasing trend of $\mathrm{pH}$ with depth across all the zones. Its highest $\mathrm{pH}$ is in the oxidised zone. The highest $\mathrm{pH}$ in the oxidised zone is displayed by Site C at 3.5.

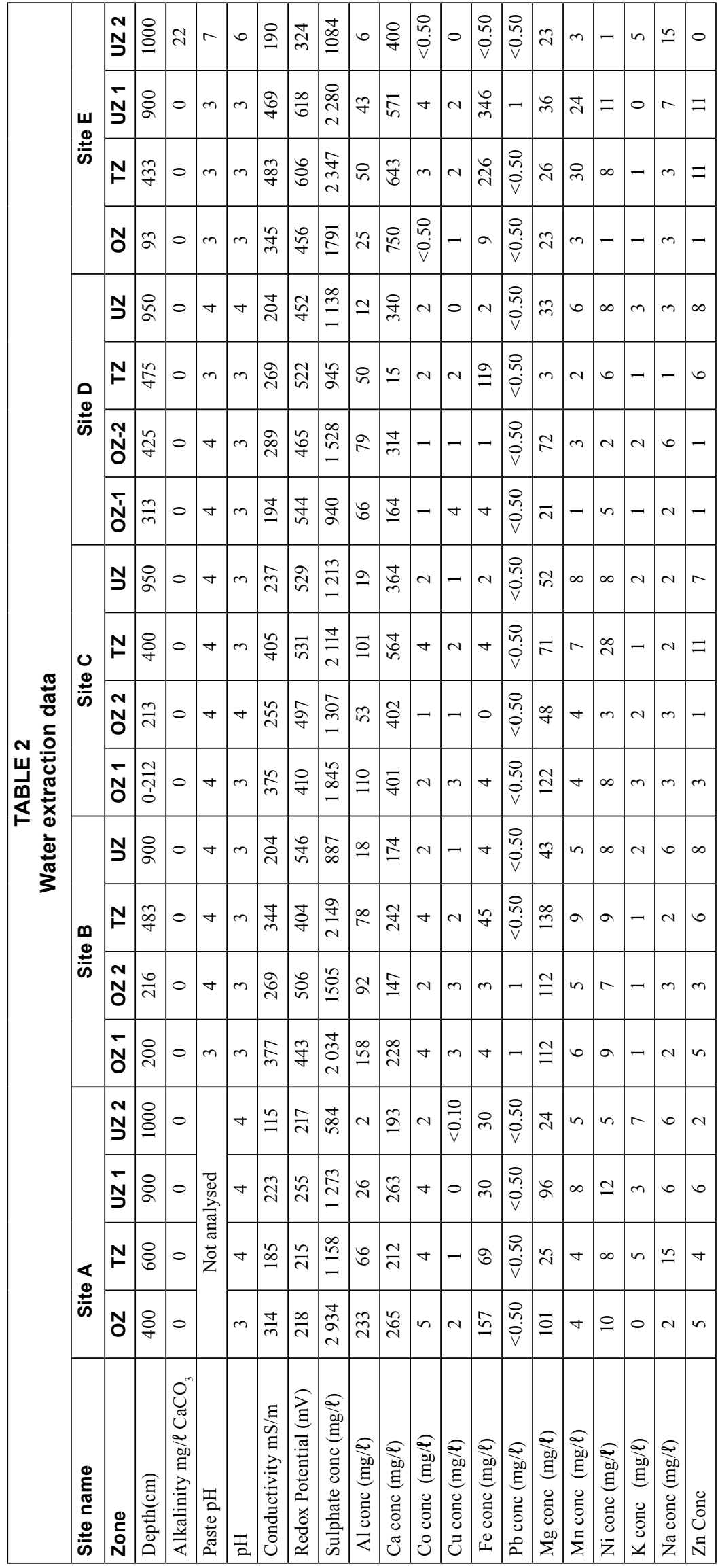




\begin{tabular}{|c|c|c|c|c|c|c|c|c|c|c|}
\hline \multicolumn{11}{|c|}{$\begin{array}{c}\text { TABLE } 3 \\
\text { Results of XRD analysis }\end{array}$} \\
\hline Zone & Pyrite & \begin{tabular}{|l|} 
Jarosite \\
\end{tabular} & Chloritoid & K-Feldspar & Quartz & Mica & Chlorite & Pyrophyllite & Clay & Gypsum \\
\hline Site A Oz & 0 & 2 & - & 0 & 80 & 8 & 8 & - & 0 & 1 \\
\hline Site A Tz & 1 & 1 & - & 1 & 82 & 9 & 7 & - & 0 & 0 \\
\hline Site A Uz 1 & 1 & 1 & - & 1 & 80 & 10 & 7 & - & 0 & 0 \\
\hline Site A Uz & 0 & 0 & - & 1 & 80 & 11 & 7 & - & 0 & 0 \\
\hline Site B Oz 1 & - & 1 & 12 & - & 69 & 9 & 8 & - & - & - \\
\hline Site B Oz 2 & - & 2 & 7 & 1 & 74 & 10 & 6 & - & - & - \\
\hline Site B Tz & 1 & 1 & 10 & 1 & 67 & 10 & 10 & - & - & - \\
\hline Site B Uz & 1 & - & 9 & - & 71 & 10 & 9 & - & - & - \\
\hline Site $\mathrm{C} \mathrm{Oz}$ & - & 1 & 13 & 1 & 72 & 6 & 6 & - & 1 & - \\
\hline Site $\mathrm{C} \mathrm{Tz}$ & 1 & - & 10 & trace & 75 & 6 & 6 & - & - & - \\
\hline Site C Uz & - & 1 & 22 & trace & 61 & 7 & 8 & - & - & - \\
\hline Site D Oz & - & 1 & 24 & - & 62 & 4 & 5 & 6 & - & - \\
\hline Site D Tz & trace & - & 16 & - & 74 & 4 & 4 & 3 & - & - \\
\hline Site D Uz & - & - & 19 & 1 & 58 & 8 & 6 & 8 & - & - \\
\hline Site $\mathrm{E} \mathrm{Oz}$ & - & 2 & 2 & - & 64 & 8 & 3 & 22 & - & - \\
\hline Site E Tz & 1 & 2 & 3 & - & 66 & 5 & 3 & 20 & - & - \\
\hline Site E Uz 1 & 2 & 1 & 2 & - & 76 & 3 & 3 & 14 & - & - \\
\hline Site E Uz 2 & - & 1 & 2 & - & 78 & 6 & 3 & 10 & - & - \\
\hline
\end{tabular}

The leaching behaviour of the following elements was determined; Al, Ca, Fe, Zn, Ni, Co, Mg and Na. At Sites A, B and $\mathrm{D}, \mathrm{Al}$ decreases from the oxidised zone through the transition to the reduced zone. However, at Site $\mathrm{C}$, it first increases from the oxidised zone to the transition then decreases in the reduced zone (Table 2). Dold and Fontbote (2002) believe that as the $\mathrm{pH}$ decreases below 3.8, $\mathrm{Al}$ is released from aluminosilicates. Only Sites A and C have a pH greater than 3.8 in the transition zone. However, Site C's reduced zone has a $\mathrm{pH}$ of less than 4.1 but still greater than 3.8. Site $\mathrm{E}$ is the only site, which shows an increase in the concentration of Al with depth. The $\mathrm{pH}$ behaviour of Site E reveals that it is also the inverse of other sites. Due to the insoluble nature of $\mathrm{Al}$, it means that as other elements are leached in the oxidised zone, it is left behind which would explain it's prevalence on the top section of the dams.

$\mathrm{Ca}$ and $\mathrm{Fe}$, which are highly influenced by the $\mathrm{pH}$ of the tailings material, show no particular trends in Table 2. The similarity in behaviour of $\mathrm{Zn}, \mathrm{Ni}$ and $\mathrm{Co}$ is also evident at these sites. It is safe to say that Sites A, B and C show that these three elements decrease with depth whereas Site D suggests an increase towards the reduced zone.

The XRD was able to detect a total number of nine different minerals (Table 3). Quartz is by far the most dominant mineral in all the study sites with Site A containing $80 \%$. Chloritoid is the overall second most dominant mineral in the study area. The laboratory analysis did not indicate any chloritoid at Site A. Site D contains the highest chloritoid content at $19.5 \%$.

In terms of the chlorite and mica content, Site B (8.25 and $9.75 \%$ respectively) dominates with Site E displaying the lowest percentage for both ( 3 and $5.5 \%$ respectively). Site A and B have the same percentage of most minerals. This includes quartz, mica, chlorite, jarosite and pyrite. This suggests that the tailings of the two dumps probably come from the same reef as the two sites lie in the same geological area (Fig. 1).

In AMD, it is common knowledge that the pyrite mineral is the main culprit. At Site A, the only pyrite that is found is in trace amounts and it is only at the transition zone. Jarosite (secondary mineral of pyrite), on the other hand is dominant at the top of the tailings where there is no detectable pyrite. The highest percentage of jarosite $(2 \%)$ is found at the oxidised zone of Sites A, B and E. Site B shows no pyrite at the oxidised zone as expected but has a $1 \%$ content at both the transition and reduced zone. Its jarosite concentration is similar to that of Site A in that there is $2 \%$ in the oxidised zone and $1 \%$ in the transition zone. Site $\mathrm{C}$ is in total agreement with what other researchers have since found in terms of the relationship between pyrite and jarosite. Its pyrite distribution is such that it is only present in the transition zone. Jarosite on the other hand, is present both in the oxidation and reduced zones and none in the transition zone. The $\mathrm{pH}$ of this site shows that the transition zone of this dam has the lowest $\mathrm{pH}$ of the entire $10 \mathrm{~m}$ profile. This explains why there is no pyrite at this zone and would also explain the presents of jarosite in the reducing zone. There seems to be further oxidation at lower levels. Site D has almost the same properties as Site $\mathrm{C}$ except that jarosite is only found in the oxidised zone. At Site $\mathrm{E}$ the highest pyrite content is at the reduced zone with none in the oxidised zone and $1 \%$ in the transition zone.

Gypsum is a secondary mineral that is formed during the dissolution of carbonate minerals such as calcite and dolomite. 

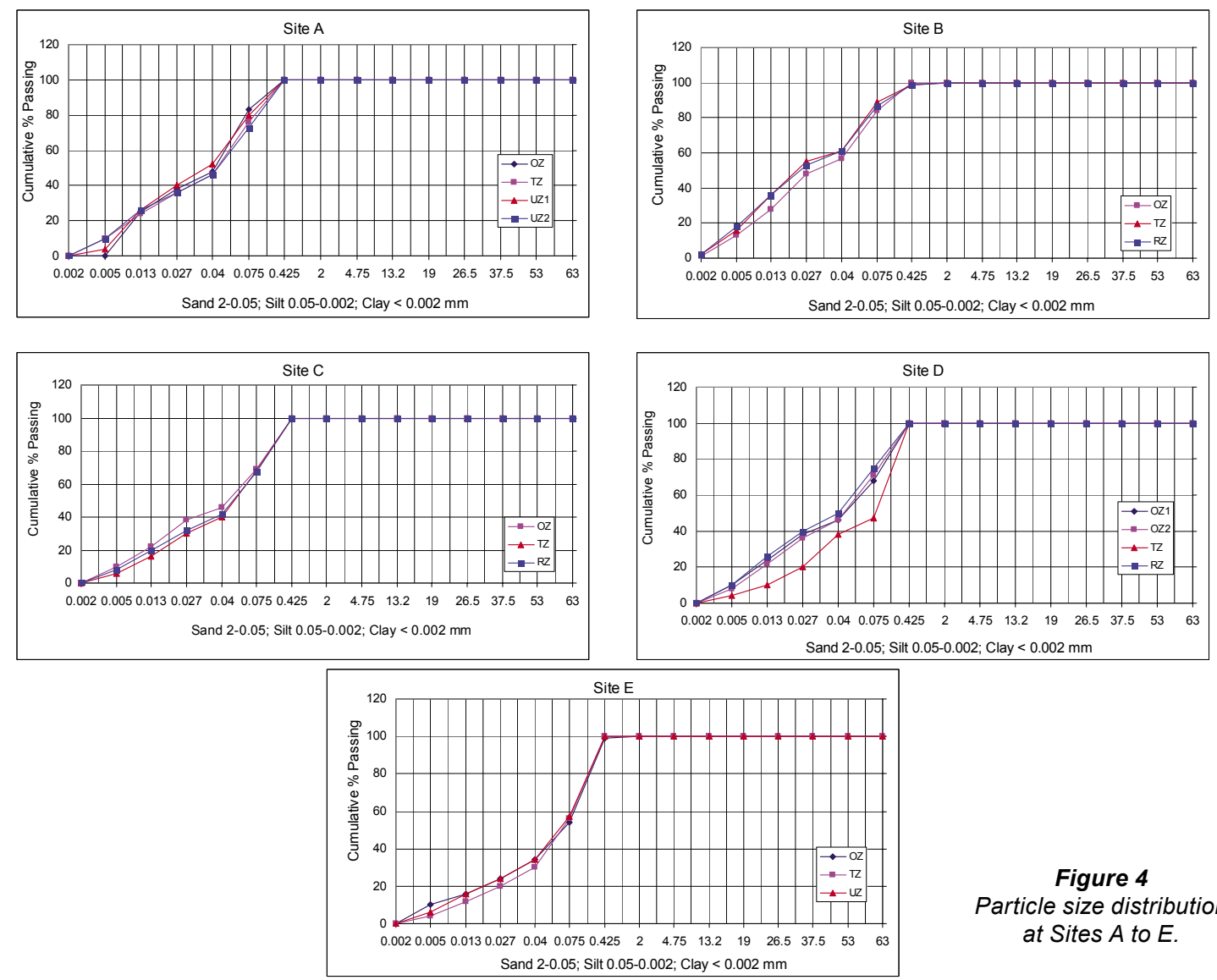

Figure 4

Particle size distribution at Sites $A$ to $E$.

Site A is the only site from which the presence of gypsum was detected. From this site, it is clear that the mineral is found in the oxidised zone and not in the transition or reduced zones. This is because most secondary minerals precipitate in the oxidised zone of tailings dams. In terms of the clay mineral content, Site $\mathrm{C}$ is the only site that contains such minerals. They are also found in the oxidised zone.

The particle size distribution data (Fig. 4) shows that all the dams except Site E can be grouped under the sandy silt class. Site E is slightly different in that it contains silty sand material. At Site A, there is no clay content in any of the three zones. The oxidised zone contains $32 \%$ of sand and $68 \%$ of silt. Sites E and B are the only two sites that contain claysized material. The presence of clay-sized material at these two sites means that they have higher water retention potential than the other three sites [Fig. 5 (b)]. Site B has the highest moisture content and water retention potential (Figs. 5 (b) and (a) respectively).

Site $\mathrm{E}$ on the other hand has the second highest moisture content and interestingly the lowest water retention potential and rainfall [Figs. 5 (b) and (c)]. This is because, although it has a clay fraction, it is not enough to provide adequate water retention, and is easily cancelled out by the higher proportion of the coarse fraction. The clay fraction at this site is only found at the reduced zone with none at the top of the tailings dam. The silt content on the other hand is dominant at the top parts. This means that the oxidised zone of Site $\mathrm{E}$ is coarser than the reduced zone.

The third site is Site D, which has interesting moisture content characteristics. It has the lowest moisture content of all the dams despite experiencing the highest rainfall of all. Its water retention potential is the second highest which should ideally qualify it as a high moisture content site. Its grain size distribution reveals that it has more sand at the transition zone at $57 \%$ and the least percentage is at the bottom of the $10 \mathrm{~m}$. The oxidised zone, however, with its low sand content contains $1 \%$ gravel probably as a result of the reworked material deposited on the dam.

The rest of the hydrological parameters are summarised in Table 4. All these parameters play a role in the development of an oxidised zone which subsequently leads to AMD formation.

Oxygen concentrations in the first $10 \mathrm{~m}$ of the six sites (i.e. A, C, D, E, F and G) varied between 0.36 and $17.2 \%$ of oxygen over the 8-week period from April to June 2005 (Fig. 6).

Within each tailings dam, oxygen concentrations remained relatively constant between 3 and $10 \mathrm{~m}$ which implies that there is not much change in oxygen concentration below $3 \mathrm{~m}$ which would explain the average oxidised zone of $2.4 \mathrm{~m}$. Previous studies of tailings dams have demonstrated that the consumption of pore-gas $\mathrm{O}_{2}$ through in situ reactions results in decreasing $\mathrm{O}_{2}$ concentrations with depth when transport is controlled by the vertical diffusion of $\mathrm{O}_{2}$ from the atmosphere (Yanful, 1993).

The presence of pyrite at lower depths coincides with the low levels of oxygen. The observed oxygen profiles could be a result of the gradual depletion of the pyrite mineral through its oxidation by oxygen and water. There is a general lack of pyrite in the top $3 \mathrm{~m}$ of the studied tailings dams, which suggests a direct proportion between the two factors. However, the consistency in $\mathrm{O}_{2}$ levels between 3 and $10 \mathrm{~m}$ suggests that its content, at this depth, is not controlled by diffusion into the tailings from the atmosphere. The profiles also suggest that the observed $\mathrm{O}_{2}$ concentrations could be a result of the gradual depletion of $\mathrm{O}_{2}$ that was incorporated within the water/tailings mixture during the construction phase. The dissolved oxygen content in rainfall is less than $1 \%$, which means that the replenishment of 


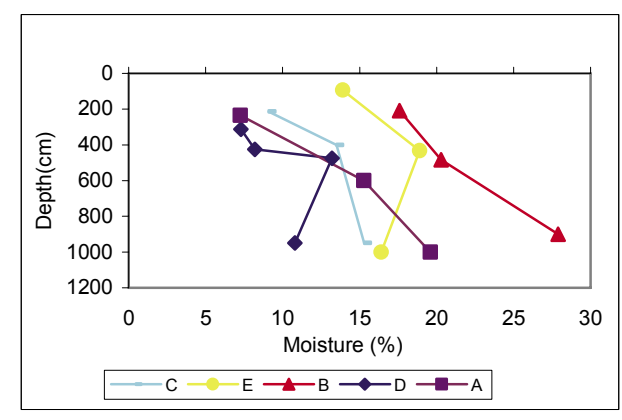

(a)

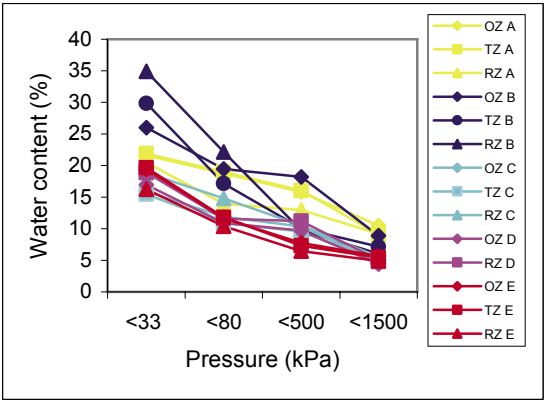

(b)

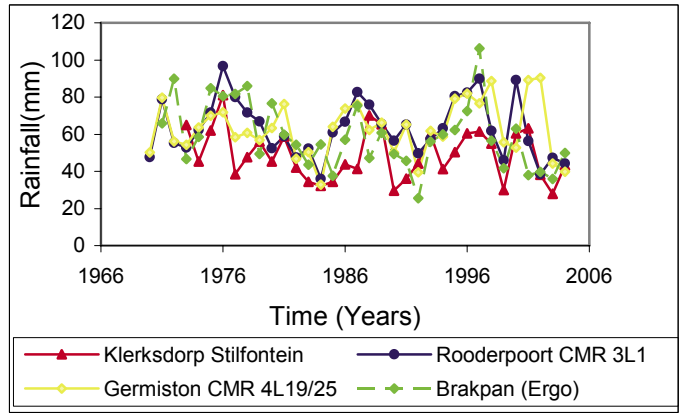

(c)

TABLE 4

Relationship between porosity, moisture content, oxygen diffusion and vegetation intensity at the studied sites. Note that Site B is excluded because no oxygen data was collected for the site.

\begin{tabular}{|c|c|c|c|c|c|}
\hline Site name & Zone & Porosity & $\begin{array}{c}\text { Average } \\
\text { oxygen } \\
\text { content }\end{array}$ & $\begin{array}{c}\text { Estimated } \\
\text { vegetation } \\
\text { cover }(\%)\end{array}$ & $\begin{array}{c}\text { Moisture } \\
\text { content } \\
(\%)\end{array}$ \\
\hline \multirow[t]{3}{*}{ Site A } & $\mathrm{OZ}$ & 0.76 & 4.1 & \multirow[t]{3}{*}{10} & 15 \\
\hline & $\mathrm{TZ}$ & 0.71 & 0.4 & & 17 \\
\hline & UZ & 0.77 & 0.49 & & 19.5 \\
\hline \multirow[t]{3}{*}{ Site C } & $\mathrm{OZ}$ & 0.54 & 13.64 & \multirow[t]{3}{*}{20} & 9.1 \\
\hline & $\mathrm{TZ}$ & 0.53 & 1.97 & & 13.5 \\
\hline & $\mathrm{UZ}$ & 0.49 & 0.43 & & 15.3 \\
\hline \multirow[t]{3}{*}{ Site D } & $\mathrm{OZ}$ & 0.56 & 8.88 & \multirow[t]{3}{*}{25} & 8.2 \\
\hline & $\mathrm{TZ}$ & 0.56 & 0.68 & & 13.2 \\
\hline & UZ & 0.53 & 0.405 & & 10.8 \\
\hline \multirow[t]{3}{*}{ Site E } & $\mathrm{OZ}$ & 0.49 & 5.42 & \multirow[t]{3}{*}{0} & 13.9 \\
\hline & $\mathrm{TZ}$ & 0.42 & 1.17 & & 18.9 \\
\hline & UZ & 0.46 & 0.53 & & 16.4 \\
\hline \multirow{3}{*}{$\begin{array}{l}\text { Site F } \\
\text { S }\end{array}$} & $\mathrm{OZ}$ & $\#$ & 3.62 & \multirow[t]{3}{*}{4} & $\#$ \\
\hline & $\mathrm{TZ}$ & $\#$ & 0.46 & & $\#$ \\
\hline & UZ & $\#$ & 0.36 & & $\#$ \\
\hline \multirow[t]{3}{*}{ Site G } & $\mathrm{OZ}$ & 0.48 & 9.67 & \multirow[t]{3}{*}{8} & $\#$ \\
\hline & $\mathrm{TZ}$ & 0.46 & 7.73 & & $\#$ \\
\hline & UZ & 0.42 & 0.66 & & \# \\
\hline
\end{tabular}

\# Data not available

oxygen by this source is not significant enough to push the oxygen values above 1\% (Standard Methods, 1995; Michaud, 1991 and Moore, 1989).

In Fig. 6, it can be seen that the oxygen concentration of Site $\mathrm{D}$ is higher that of the other dams. This is mainly due to the mature vegetation cover that prevails on the surface of the dam. Oxygen diffusion is dependent on a variety of parameters in a tailings dam that interact to facilitate the oxidation of sulphides.
Figure 5

Hydraulic properties of the studied Witwatersrand tailings dams showing (a) moisture content (b) water retention characteristics, (c) rainfall
It has been shown that Site $\mathrm{D}$ generally experiences the highest rainfall with Site E having had the lowest (Fig 5(c)]. Site $\mathrm{C}$ has the second highest with Site A third. It is observed that the dams with high rainfall get more oxygen supply in that rainwater contains $1 \%$ of oxygen (Michaud, 1991: Moore, 1989) which means that some oxygen is added to the impoundment by the rainfall gas fraction.

From all the data presented thus far, no single parameter has appeared as a yardstick to determine the amount of oxygen that is retained by the various dams. Vegetation on the 6 tailings dams (excluding Site B) was quantitatively estimated and a rating system established in an attempt to solve this quandary. The established rating system shows that Site D had the thickest and oldest vegetation, followed by Sites A, C, G, F and lastly E (Table 4). Although vegetation plays an important role in controlling oxygen diffusion in tailings dams, the age of the dam is believed to carry significant weight. According to the data obtained from the different mines, the dams have three different age groups, the oldest site is A which is over 50 years old, followed by the second group which includes Sites B, C, D, and E which were decommissioned between 1970 and 1980 and lastly $\mathrm{F}$ and $\mathrm{G}$ which were decommissioned in the late 1990s.

Site D had the thickest and oldest vegetation made up of old trees and grass. Site C follows closely to D in that, although the trees were not as dense as at Site D, they were also densely packed. The old trees at Site D had bigger roots grounded at greater depths. Site A does not have a dense population of trees but very thick grass with a thick root system. This would explain why it is third in the oxygen diffusion rankings. Site $G$ is fourth 
Figure 6 sites with depth from 1 to $10 \mathrm{~m}$
Oxygen readings in the six studied

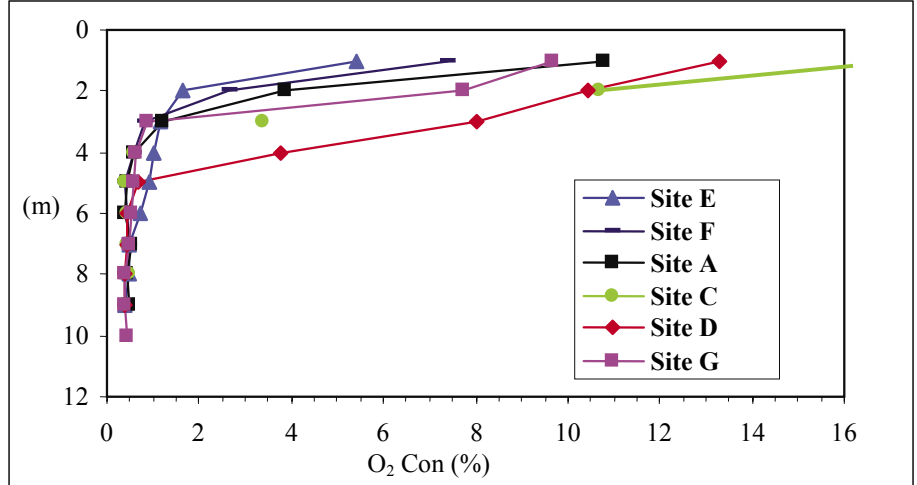

is terms of the vegetation distribution with densely populated shrubs but no trees.

Site F contained scattered and small shrubs, which therefore have smaller roots. Their impact is reduced by the intensity through which they are scattered. Site E does not have any trees or grass whatsoever, most particularly where the MLGS was constructed. A comparison between the ages of the various dams shows that Site $G$ is younger than F (Table 1) but due to the intensity and development of vegetation, the former contains more oxygen. This clearly shows that vegetation intensity strongly influences oxygen diffusion. Older vegetation is well established and has deep penetrating roots such as those seen at Site D. A dam without any trees or roots does not provide any preferential pathways for easier movement of water and gases, in this case oxygen and Site E bears testimony to this statement.

\section{Conclusions}

Having discussed all the factors, it becomes clear that water and oxygen are the primary prerequisites needed for sulphide oxidation to occur, but they carry varying weights. Oxygen seems to play a bigger role than water; most dams have higher moisture contents within the first $10 \mathrm{~m}$ and only have an average oxidised zone of $2.4 \mathrm{~m}$. Oxygen on the other hand is only present within the top $3 \mathrm{~m}$ of the tailings dam and coincidentally this is where sulphide oxidation in most cases ceases. It can be concluded that:

- At least the first $10 \mathrm{~m}$ of the Witwatersrand tailings dams are acidic. The different $\mathrm{pH}$ ranges in the three zones are as follows; oxidised zone (3.06 to 3.6); transition zone (2.52 to 4.1); reduced zone (2.52 to 4.11$)$.

- In addition to quartz, other minerals in the Witwatersrand tailings include pyrophylitte ( 3 to $22 \%$ ) chloritoid ( 2 to $20 \%$ ), mica (3 to $11 \%$ ), chlorite (3-10\%), jarosite (1 to $2 \%$ ), pyrite (1 to $2 \%)$, gypsum $(\sim 1 \%)$, and clay minerals $(\sim 1 \%)$.

- Pyrite is not found in the top $3 \mathrm{~m}$ of the Witwatersrand tailings dams.

- Oxygen in the Witwatersrand tailings dams varies from $0.36 \%$ in the reduced zone to $17.2 \%$ in the oxidised zone.

- Considerable oxygen is only found in the top $4 \mathrm{~m}$ of the Witwatersrand tailings dams.

- There is no significant variation in oxygen between 4 and $10 \mathrm{~m}$.

- Moisture content is inversely proportional to oxygen concentration. The high moisture content of Site E, at an average of $17 \%$ is inversely proportional to the low oxygen content (which is an average of $2.8 \%$ in the top $3 \mathrm{~m}$. Sites C and D have the lowest moisture content of all the dams with average values of 12 and $9.75 \%$ respectively. These two have the highest oxygen content.

- Sites with dense vegetation have elevated oxygen concentrations. The thick vegetation at Site D certifies this point as does the barren Site E.

The development of oxidised zones in the Witwatersrand tailings dams is limited by the amount of oxygen that diffuses through the dam. A reduction in the porosity of the material would be inhibitory to sulphide oxidation development. This is because it was seen that porosity, particularly, secondary porosity (caused by roots), is one of the main factors controlling oxygen diffusion and moisture content. The introduction of trees during the rehabilitation process accelerates the sulphide oxidation process due to secondary porosity. A solution to this would be the establishment of a thick soil cover that would provide a medium for plant growth; this way, even when the trees grow, the fracturing will only occur on the soil cover. Another solution is to plant trees or shrubs that are known to develop shallow roots (e.g. rhizomes). This way the roots do not penetrate the tailings material but the introduced soil cover instead.

The 2 to $3 \mathrm{~m}$ average oxidised zone thickness in the Witwatersrand tailings dams will remain unchanged for years to come provided the same mineral processing methods are used. This means that the increasing ages of the dams will not lead to any significant oxidised zone development. Although the rate of migration of the oxidation front is unknown the available data has shown that it will take a considerable (i.e. hundreds if not thousands) number of years for the entire dam to be oxidised. Further modelling studies need to be undertaken to fortify this hypothesis. When the trees age, they also increase in size and their roots penetrate deeper into the tailings in search of food and water.

\section{Acknowledgements}

This research was made possible through the support of the Water Research Commission of South Africa (WRC) www.wrc. org.za) and Pulles Howard and De Lange Inc (PHD) (now part of Golder and Associates).

\section{References}

DOLD B and FONTBOTE L (2002) A mineralogical and geochemical study of element mobility in sulfide mine tailings of $\mathrm{Fe}$ oxide $\mathrm{Cu}-\mathrm{Au}$ deposits from the Punta del cobre belt, northern Chile. Chemical Geology 189 including Isotope Geosciences 189 (c) 2002. Elsevier Science BV. 135-163.

ELBERLING B, NICHOLSON RV and DAVID DJ (1993) Field evaluation of sulphide oxidation rates. Nordic Hydrol. 24 323-338.

FERGUSON KD and ERICKSON PM (1988) Pre-mine prediction of AMD. In: Willem Salomons and Ulrich Forstner (eds.) Dredged 
Material and Mine Tailings. Copyright by Springer Verlag, Berlin Heidelberg. 1988.

GOLDFIELDS, DRIEFONTEIN GOLD MINE, GEOLOGY DEPARTMENT (2004) Geology of Driefontein Gold Mine, Unpublished.

MICHAUD JP (1991) A Citizen's Guide to Understanding and Monitoring Lakes and Streams. Publ. \#94-149. Washington State Dept. of Ecology, Publications Office, Olympia, WA, USA (360) 407-7472.

MOORE ML (1989) NALMS Management Guide for Lakes and Reservoirs. North American Lake Management Society, PO Box 5443, Madison, WI, 53705-5443, USA.

SHAW SA (2004) Determining the Long Term Persistence of Mercury Releases to the Environment from Cyanide-Rich Gold Mine
Tailings. Unpublished M.Sc. Thesis, The University of New Brunswick, USA.

STANDARD METHODS (1995) Standard Methods for the Examination of Water and Wastewater (19th edn.). American Public Health Association (APHA) American Water Works Association, and Water Pollution Control Federation. Washington, D.C.

TYSON PD and WILCOCKS JRN (1971) Rainfall variation over Johannesburg - the local climate over Johannesburg. Department of Geography and Environmental Studies, Universtiy of Witwatersrand, Johannesburg. Occasional paper. $428 \mathrm{pp}$.

YANFUL EK (1993) Oxygen diffusion through soil covers on sulphidic mine tailings. J. Geotech. Eng. 119 1207-1228. 